Jurnal Pemikiran \& Penelitian Psikologi

\title{
PSIKOLOGIA
}

p-ISSN: $185-0327$

e-ISSN: $2549-2136$

www.jurnal.usu.ac.id/psikologia

\section{HUBUNGAN KEPEMIMPINAN TRANSFORMASIONAL DENGAN KOMITMEN ORGANISASI PADA KARYAWAN PT X}

CORRELATION OF TRANFORMATIONAL LEADERSHIP WITH ORGANIZATIONAL COMMITMENT IN EMPLOYEES AT PT $X$

Farahdiba Mutia , Emmy Mariatin

Psikologia: Jurnal Pemikiran \& Penelitian Psikologi

Tahun 2018, Vol. 13, No. 2, hal.101-119

Artikel ini dapat diakses dan diunduh pada:

www.jurnal.usu.ac.id/psikologia

\section{Dipublikasikan oleh:}

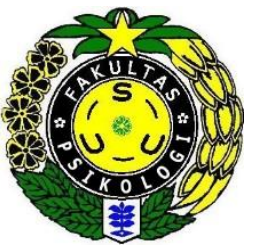

Fakultas Psikologi

Universitas Sumatera Utara

J1. Dr. Mansyur No. 7 Medan. Telp/fax: 061-8220122

Email: psikologia@usu.ac.id 


\title{
HUBUNGAN KEPEMIMPINAN TRANSFORMASIONAL DENGAN KOMITMEN ORGANISASI PADA KARYAWAN PT $X$
}

\author{
Farahdiba Mutia, Emmy Mariatin \\ Universitas Sumatera Utara
}

\begin{abstract}
ABSTRAK
Penelitian ini bertujuan untuk mengetahui hubungan kepemimpinan transformasional dengan komitmen organisasi pada karyawan PT X. Subjek penelitian ini berjumlah 193 orang dan teknik pengambilan sampel yaitu probability sampling. Data dikumpulkan dengan menggunakan skala kepemimpinan transformasional Bass dan Avolio dan skala komitmen organisasi (komitmen afektif, komitmen berkelanjutan dan komitmen normatif) Meyer dan Allen. Data dianalisis secara statistik menggunakan Pearson Product Moment. Hasil analisis statistik menunjukkan bahwa terdapat hubungan kepemimpinan transformasional dengan komitmen afektif pada perusahaan ini adalah positif dan signifikan dengan kekuatan korelasi tergolong lemah.Hal ini menunjukkan bahwa semakin baik kepemimpinan transformasional yang diberikan makan akan meningkatkan komitmen afektif, komitmen berkelanjutan dan komitmen normatif pada karyawan di PT X.
\end{abstract}

Kata Kunci: Kepemimpinan Transfomasional, Komitmen Afektif, Komitmen Berkelanjutan dan Komitmen Normatif

\section{CORRELATION OF TRANFORMATIONAL LEADERSHIP WITH ORGANIZATIONAL COMMITMENT IN EMPLOYEES AT PT $X$.}

\begin{abstract}
The purpose of this study is to determine the relationship between transformational leadership with organizational commitment at PT X employees. The respondents were 193 employees and technique sampling was probability sampling. Data was collected using transformational leadership scale by Bass and Avolio and organizational commitment scale (affective commitment, continuance commitment and normative commitment) by Meyer and Allen. Data were statically analyzed using Pearson Product Moment. Statically analyzed showing that the relationship between transformational leadership with affective commitment in this organization was positive and significant with low strength of correlationThis mean the better transformational leadership provide will enhance the affective commitment, continuance commitment and normative commitment from employees at PT X.
\end{abstract}

Keywords: Transformational Leadership, Affective Commitment, Continuance Commitment and Normative Commitment

*Korespondensi mengenai penelitian ini dapat dilayangkan kepada: psikologia@usu..ac.id
Rekomendasi mensitasi:

Mutia, F., Mariatin, E. (2018). Hubungan

Kepemimpinan Transformasional dengan Komitmen Organisasi pada Karyawan PDAM Tirtanadi Prov. Sumatera Utara. Psikologia :Jurnal Pemikiran dan Penelitian Psikologi, 13(2), 101-119 
Era globalisasi saat ini menuntut perusahaan untuk dapat terus berubah dan meningkatkan kemampuan seiring dengan munculnya tantangan bagi perusahaan untuk menjalankan perusahaannya secara berkelanjutan. Untuk tercapainya hal tersebut, perusaahaan tidak mungkin terlepas dari sumber daya manusia yang ada.Sumber daya manusia dalam suatu perusahaan merupakan faktor yang sangat penting dalam sebuah organisasi, baik pada organisasi dalam skala besar maupun kecil serta organisasi formal dan nonformal. Sebab sumber daya manusia dipandang sebagai unsur yang sangat menentukan dalam proses berkembangnya perusahaan. Karyawan sebagai salah satu sumber daya manusia mempunyai kewajiban untuk loyal kepada perusahaan karena dengan kesetiaan yang dimiliki oleh karyawan akan sangat berdampak kepada kinerja perusahaan.

Konsultan sumberdaya manusia terkemuka Watson Wyatt dengan tema WorkIndonesia 2004/2005 membuat sebuah penelitian yang paling komprehensif dan yang pertama dilakukan di Indonesia dan Asia mengenai komitmen, sikap, dan pandangan karyawan. Survei ini diikuti oleh lebih dari 8.000 responden aktual dari 46 perusahaan di 14 industri utama di Indonesia. Jumlah responden itu menyumbang 9\% dari total sampel penelitian WorkAsia, yang dilakukan di 11 negara, meliputi 515 perusahaan, dan 115.000 responden aktual.

Fokus dalam survey ini adalah untuk mengukur aspek komitmen (commiment), keselarasan kerja (alignment), dan pemberdayaan karyawan (enablement) - 3 hal yang berdampak besar terhadap fondasi perusahaan.

$$
\text { Sifat mendua (ambiguity) }
$$

karyawan Indonesia terlihat dalam aspek komitmen. Sebanyak $85 \%$ karyawan merasa bangga bekerja di perusahaan mereka (angka ini melebihi karyawan Asia Pasifik yang hanya 77\%), sebanyak $80 \%$ karyawan yakin terhadap keberhasilan jangka panjang perusahaan (angka ini melebihi Asia Pasifik yang hanya $72 \%$ ), tetapi hanya 35\% karyawan Indonesia yang ingin bertahan di perusahaan kendati pekerjaan di perusahaan lain itu hampir sama saja dalam hal gaji, jabatan, dan skop pekerjaan. Bandingkan misalnya dengan hasil survei untuk tingkat Asia Pasifik di mana 57\% karyawan memilih untuk bertahan kendati tersedia jabatan serupa di perusahaan lain. Dari penjabaran tersebut menunjukkan bahwa responden dari Indonesia memiliki komitmen organisasi yang rendah. Hal ini membawa dampak pada prestasi kerja karyawan yang rendah, karena karyawan tidak bekerja dengan serius. Selain itu juga menyebabkan kerugian yang besar bagi perusahaan, antara lain pindah kerja dan pemogokan (sumber: www.portalhr.com)

Sumber: Divisi SDM PT X

Dari tabel 1.1 menunjukkan bahwa frekuensi keterlambatan pegawai dinilai cukup tinggi. Dapat dilihat dalam jangka waktu enam bulan, terdapat 758 kali keterlambatan. Keterlambatan yang dilakukan satu hingga tiga kali dalam sebulan tidak mendapat surat teguran dari perusahaan. Namun keterlambatan lebih dari tiga kali dalam sebulan mendapatkan surat teguran dari perusahaan. Dari tabel tersebut dapat disimpukan bahwa keterlambatan satu hingga tiga kali dalam sebulan memiliki frekuensi yang lebih besar ketimbang keterlambatan lebih dari tiga kali dalam sebulan.

$$
\text { Meyer \& Allen (1990) }
$$
menyatakan bahwa ketiga komponen komitmen (berkelanjutan, normatif dan afektif) secara konseptual maupun empiris terpisah satu sama lain. Walaupun masing- 
masing komponen mewakili keterkaitan antara individu dengan organisasi, namun bentuk keterikatannya bervariasi. Penyebab dan dampaknyapun berbedabeda (Meyer, Allen \& Smith, 1993).

Kepemimpinan transformasional merupakan salah satu aspek yang dapat mempengaruhi komitmen organisasi (Desianty, 2005). Dalam memelihara komitmen organisasi, peran seorang pemimpin sangat dibutuhkan dan kepemimpinan yang efektif menjadi syarat utama. Penelitian Budiarto dan Selly (2004) yang menunjukkan bahwa komitmen transformasional memiliki hubungan yang positif dan signifikan dengan komitmen.

Salah satu dimensi kepemimpinan transformasional, motivasi inspirasi mengemukakan bahwa pemimpin dapat menginspirasi serta memotivasi bahwahan untuk komitmen dan menjadi bagian dari visi organisasi. Penelitian Steers \& Porter (1983) yang menemukan salah satu faktor yang mempengaruhi terbentuknya komitmen organisasi adalah hubungan atasan dan bawahan, kualitas hubungan atasan dan bawahan merupakan hasil pembentukan peran yang dilakukan sorang atasan terhadap bawahan.

Berbagai gaya kepemimpinan akan memiliki andil dalam perilaku pemimpin untuk menjalankan tugasnya. Seorang pemimpin memiliki jiwa kepemimpinan, daya inovasi dan kreativitas yang tinggi agar perusahaan dapat maju dengan pesat (Budiarto \& Selly, 2004). Welch, CEO dari General Electric menyatakan bahwa apabila perubahan yang terjadi di luar perusahaan kita lebih cepat atau tidak dapat diikuti kecepatan perubahan di dalam perusahaan kita, maka akhir dari perusahaan sudah sangat dekat (Daft, 1999).

Penelitian mengenai kepemimpinan transformasional dan komitmen organisasi yang dilakukan oleh Ismail dkk (2011) terhadap 118 orang karyawan yang bekerja di salah satu perusahaan cabang Amerika Serikat di Malaysia Timur menunjukkan bahwa terdapat hubungan positif dan signifikan antara kepemimpinan transformasional dengan komitmen organisasi dengan empowerment sebagai variabel mediasi.

Kepemimpinan

(leadership)

merupakan inti dari manajemen karena kepemimpinan merupakan suatu penggerak khususnya sumber daya manusia dalam suatu perusahaan. Kualitas dari pemimpin sering kali di anggap sebagai faktor terpenting dalam keberhasilan atau kegagalan organisasi (Bass, 1990). Begitu pentingnya peran pemimpin sehingga isu mengenai pemimpin tetap menjadi fokus yang menarik perhatian para peneliti.

Perusahaan yang sudah berdiri lebih dari satu abad ini tentunya sudah berulang kali terjadi pergantian pemimpin. Pemimpin perusahaan yang dalam hal ini direksi berperan sangat penting dalam pengambilan keputusan di perusahaan ini. Seperti yang diungkapkan oleh salah satu karyawan berikut ini.

"Kalau disini semua keputusan ada ditangan direksi. Kami hanya meneruskan hasil dari keputusan direksi dalam bentuk laporan saja. Usulan bisa saja dibuat tetapi bisa ditindak lanjuti kalau sudah ada acc dari direksi"

(Komunikasi Personal, 25 Januari 2014)

Gaya kepemimpinan yang ditunjukkan oleh pemimpin saat ini mengarah kepada gaya kepemimpinan transformasional dimana pemimpin lebih mengarah pada peningkatan kesejahteraan karyawan. Berikut beberapa hal 
peningkatan kesejahteraan yang diungkap oleh salah satu karyawan.

"Banyaklah peningkatan kesejahteraan karyawan yang dibuat. Misalnya biaya pensiunan sekarang udah naik. Gaji juga Alhamdulillah tahun ini naik.

Trus juga dulukan kalau opname hanya bisa untuk karyawan, istri dan anak-anak aja, sekarang kalau istri yang kerja disini, suaminya pun ditanggung juga biaya berobatnya. Sama ini, sekarang honor gak ada lagi jadwal kerja hari minggunya."

(Komunikasi Personal, 25 Januari 2014)

Kepemimpinan merupakan proses interaksi antara atasan dan bawahan. Dalam proses interaksi yang terjadi antara pimpinan dan bawahan, berlangsung proses saling mempengaruhi dimana pemimpin berupaya agar bawahannya berperilaku sesuai dengan harapannya. Pola interaksi inilah yang kemudian akan menentukan derajat keberhasilan pemimpin dalam kepemimpinannya. Salah satu gaya kepemimpinan yang substansial dan dapat memperbaharui organisasi adalah kepemimpinan transformasional (Daft, 1999).

Pemimpin menciptakan visi dan lingkungan yang mengarah ke tujuan perusahaan dengan memberikan motivasi kepada bawahan untuk berprestasi. Hal ini akan berimplikasi pada bawahan yang percaya, kagum, loyal dan hormat pada atasan (Muhdianto, 2011). Hubungan dan kualitas antara atasan dan bawahan merupakan hasil pembentukan peran yang dilakukan oleh atasan terhadap bawahan. Maka dari itu, dengan kualitas hubungan yang baik akan terjadi seringnya diskusi dalam penyelesaian suatu masalah pekerjaan.
Dari penjabaran mengenai komitmen organisasi dan kepemimpinan transformasional di atas, peneliti ingin mengetahui hubungan antara kepemimpinan transformasional dengan komitmen organisasi pada karyawan di PT $\mathrm{X}$.

\section{Komitmen Organisasi}

Kreitner dan Kinicki (2003) mendefinisikan komitmen organisasi sebagai tingkat kepercayaan dan penerimaan karyawan terhadap tujuan organisasi dan mempunyai keinginan untuk tetap ada dalam organisasi tersebut. Komitmen organisasi juga didefinisikan sebagai suatu keadaan dimana seorang karyawan membela organisasi tertentu serta tujuan-tujuan dan keinginannya untuk mempertahankan keanggotaan dalam organisasi tersebut (Robbins, 2008). Mowday dkk

mendefinisikan komitmen organisasi sebagai kekuatan relatif dari identifikasi individu dan keterlibatan dalam organisasi khusus, meliputi kepercayaan, dukungan terhadap tujuan dan nilai-nilai organisasi dan keinginan yang kuat untuk memelihara keanggotaan dalam organisasi. Komitmen organisasi melibatkan hubungan aktif dengan organisasi kerja yang memiliki tujuan memberikan segala usaha demi keberhasilan organisasi kerja yang bersangkutan (Mowdays dkk, 1979).

\section{Kepemimpinan Transformasional}

Kepemimpinan transformasional adalah kepemimpinan yang bersifat sosialisasi dan peduli dengan kebaikan bersama sehinga mengalahkan kepentingan sendiri demi kebaikan orang lain (Howell \& Avolio, 1993). Kepemimpinan transformasional peduli 
dengan perbaikan kinerja pengikut dan mengembangkan pengikut ke potensi maksimal mereka (Avolio, 1999; Bass \& Avolio, 1990).

Menurut Burns (1978), kepemimpinan transformasional adalah sebuah proses antara pimpinan dan bawahan saling meningkatkan tingkat moralitas dan motivasi satu sama lainnya, serta dapat diterapkan oleh siapa saja dalam organisasi pada kedudukan apapun. Pemimpin transformasional juga harus mempunyai kemampuan untuk menyamakan visi masa depan dengan bawahannya, serta mempertinggi kebutuhan bawahan pada tingkat yang lebih tinggi dari apa yang mereka butuhkan.

Bass (1985) menyatakan bahwa kepemimpinan transformasional memotivasi pengikut untuk melakukan lebih dari yang diharapkan dengan meningkatkan pemahaman pengikut mengenai kegunaan dan nilai dari tujuan yang rinci dan ideal, memuat pengikut mengalahkan kepentingan sendiri demi tim atau organisasi dan menggerakkan pengikut untuk memenuhi kebutuhan tingkatan yang lebih tinggi.

\section{Karyawan}

Pengertian karyawan menurut Kamus Besar Bahasa Indonesia adalah orang yang bekerja pada suatu lembaga (kantor, perusahaan, dsb) dengan mendapat gaji (upah). Menurut Soedaryono (2006), karyawan adalah seseorang yang melakukan penghidupannya dengan bekerja dalam kesatuan organisasi, baik kesatuan kerja pemerintah maupun kesatuan kerja swasta.

Robbins (2006) mendefinisikan karyawan adalah orang pribadi yang bekerja pada pemberi kerja, baik sebagai pegawai tetap atau tidak, berdasarkan kesepakatan kerja baik tertulis maupun tidak tertulis, untuk melaksanakan suatu pekerjaan dalam jabatan atau kegiatan tertentu yang ditetapkan oleh pemberi kerja. Dapat disimpulkan bahwa karyawan adalah seseorang yang bekerja di suatu organisasi dengan mendapatkan imbalan atas pekerjaan yang dilakukan sesuai dengan peraturan yang ditetapkan.

\section{METODE \\ Identifikasi Variabel}

Penelitian ini merupakan jenis penelitan korelasional. Variabel merupakan segala sesuatu yang akan menjadi objek pengamatan penelitian. Variabel penelitian juga sering disebut sebagai faktor-faktor yang berperan dalam peristiwa atau gejala yang akan diteliti (Suryabrata, 2011). Pada dasarnya identifikasi variabel merupakan pernyataan eksplisit mengenai apa dan bagaimana fungsi variabel yang diperhatikan (Azwar, 2010). Dalam penelitian ini, variabel bebasnya adalah kepemimpinan transformasional dan variabel tergantung dalam penelitian ini adalah komitmen afektif, komitmen berkelanjutan dan komitmen normatif.

\section{Populasi dan Sampel Penelitian}

Populasi adalah wilayah generalisasi yang terdiri atas objek/subjek yang mempunyai kualitas dan karakteristik tertentu yang ditetapkan oleh peneliti untuk dipelajari dan kemudian ditarik kesimpulannya. Sedangkan sampel adalah bagian dari jumlah dan karakteristik yang dimiliki oleh populasi tersebut. Populasi dalam penelitian ini adalah seluruh karyawan PT X.

Sampel adalah bagian dari populasi yang akan diteliti atau sebagian jumlah dari karakteristik yang dimiliki oleh populasi. Sampel dalam penelitian ini 
yaitu sebanyak 193 orang karyawan yang bekerja di kantor pusat PT X.

\section{Teknik \\ Pengambilan Sampel}

Teknik pengambilan sampel yang digunakan adalah teknik probability sampling. Dengan cara probabilitas, setiap subjek dalam populasi memiliki peluang yang besarnya sudah diketahui untuk terpilih menjadi sampel (Azwar, 2010).

\section{Pengumpulan Data}

Pengumpulan data menggunakan metode survey melalui pembagian kuisioner kepada responden. Kuisioner (Azwar, 2010) adalah suatu bentuk instrument pengumpulan data yang sangat fleksibel dan relatif mudah digunakan. Data yang digunakan termasuk data factual dan oleh karena itu reabilitas hasilnya sangat tergantung pada subjek penelitian sebagai responden. Peneliti memilih untuk menggunakan metode survei dengan menyebarkan kuisioner secara langsung kepada responden adalah agar peneliti dapat menghemat waktu, tenaga, dan biaya. Penggunaan metode tersebut juga diharapkan dapat mengungkap persepsi responden yang sebenarnya.

\section{Skala Komitmen}

Skala komitmen yang digunakan dalam penelitian ini merupakan skala komitmen oleh Meyer dan Allen (1990). Skala komitmen dijabarkan dalam bentuk aitem-aitem dengan menggunakan lima alternatif jawaban, yaitu: Sangat Tidak Setuju, Tidak Setuju, Netral, Setuju dan Sangat Setuju. Skor dimulai dari 1 sampai dengan 5. "Sangat Tidak Setuju" mendapat skor 1 (satu), "Tidak Setuju" mendapat skor 2 (dua), "Netral" mendapat skor 3 (tiga), "Setuju" mendapat skor 4 (empat) dan "Sangat Setuju" mendapat skor 5 (lima), dengan pemberian skor yang berbeda untuk aitem favorable dan aitem unfavorable. Skor total yang diperoleh subjek menggambarkan komitmen subjek terhadap organisasinya. Semakin tinggi skor subjek maka semakin tinggi pula keterikatannya dengan organisasi dan semakin kecil keinginannya untuk meninggalkan organisasi dan sebaliknya.

Ke-tiga dimensi komitmen dikembangkan dalam beberapa pernyataan dalam bentuk aitem yang terdiri dari pernyataan favourable dan unfavourable. Berikut tabel 3.1 menyajikan Blue Print skala komitmen organisasi:

Tabel 3.1. Blue Print Skala Komitmen Organisasi

\begin{tabular}{|c|c|c|c|c|}
\hline No. & Dimensi & $\begin{array}{l}\text { Favou } \\
\text { rable }\end{array}$ & $\begin{array}{l}\text { Unfavoura } \\
\text { ble }\end{array}$ & Total \\
\hline 1 & $\begin{array}{l}\text { Komitme } \\
\text { n Afektif }\end{array}$ & $\begin{array}{l}1, \quad 4 \\
7,19\end{array}$ & $\begin{array}{l}10,13,16, \\
22\end{array}$ & 8 \\
\hline 2 & $\begin{array}{l}\text { Komitme } \\
\mathrm{n} \\
\text { Berkelanj } \\
\text { utan }\end{array}$ & $\begin{array}{l}5,8, \\
14, \\
17, \\
20,23\end{array}$ & 2,11 & 8 \\
\hline 3 & $\begin{array}{l}\text { Komitme } \\
\mathrm{n} \\
\text { Normatif }\end{array}$ & $\begin{array}{l}3,12, \\
15, \\
18,21\end{array}$ & $6,9,24$ & 8 \\
\hline $\begin{array}{l}\text { Jumlat } \\
\text { Aitem }\end{array}$ & h Total & 15 & 9 & 24 \\
\hline
\end{tabular}

1. Skala Kepemimpinan Transformasional

\section{Skala kepemimpinan transformasional}

Skala kepemimpinan transformasional yang digunakan dalam penelitian ini merupakan skala yang dimodifikasi dari Multifactor Leadership Questionaire (MLQ), 1995 oleh Bernard M. Bass dan Bruce J. Avolio, Mind Garden, Inc. Pertanyaan yang ada dalam alat ukur berikut ini menggambarkan gaya 
kepemimpinan atasan menurut persepsi bawahan secara individu. Pertanyaan yang terdapat dalam daftar berikut dijawab dengan mengacu kepada tingkat keseringan munculnya perilaku pemimpin untuk setiap pertanyaan dengan lima alternatif jawaban, yaitu: Tidak Pernah, Kadang-kadang, Cukup sering, Sering dan Sering sekali.

Skor dimulai dari 1 sampai dengan 5 . "Sering sekali" mendapat skor 5 (lima), "Sering" mendapat skor 4 (empat), "Cukup sering" mendapat skor 3 (tiga), "Kadang-kadang" mendapat skor 2 (dua) dan "Tidak pernah" mendapat skor 1 (satu), dengan pemberian skor yang berbeda untuk aitem favorable dan aitem unfavorable. Skor total yang diperoleh subjek menggambarkan persepsi subjek terhadap gaya kepemimpinan sang pemimpin. Semakin tinggi skor total yang diperoleh subjek memberitahukan bahwa semakin baik persepsi subjek terhadap karakteristik kepemimpinan trasformasional yang dijalankan pemimpinnya.

Ke-empat dimensi kepemimpinan transformasional dikembangkan dalam beberapa pernyataan dalam bentuk aitem yang terdiri dari pernyataan favourable dan unfavourable. Berikut tabel 3.2 menyajikan blue print dari skala kepemimpinan transformasional:

\section{Tabel 3.2 Blue Print Skala Kepemimpinan Transformasional}

\begin{tabular}{|c|c|c|c|c|}
\hline & $\begin{array}{l}\text { ruh } \\
\text { Ideal }\end{array}$ & $\begin{array}{l}10, \quad 21 \\
25,29\end{array}$ & & \\
\hline 2 & $\begin{array}{l}\text { Motiva } \\
\text { si } \\
\text { Inspira } \\
\text { si }\end{array}$ & $\begin{array}{l}3,5,11 \\
16, \quad 18 \\
30\end{array}$ & 22,26 & 8 \\
\hline 3 & $\begin{array}{l}\text { Stimul } \\
\text { asi } \\
\text { Intelek } \\
\text { tual }\end{array}$ & $\begin{array}{ll}1,2, & 13, \\
15, & 19 \\
31 & \end{array}$ & 23,27 & 8 \\
\hline 4 & $\begin{array}{l}\text { Perhati } \\
\text { an } \\
\text { Individ } \\
\text { ual }\end{array}$ & $\begin{array}{l}6,8,12, \\
14, \quad 20 \\
24, \\
32\end{array}$ & - & 8 \\
\hline \multicolumn{2}{|c|}{$\begin{array}{l}\text { Jumlah } \\
\text { Total Aitem }\end{array}$} & 27 & 5 & 32 \\
\hline
\end{tabular}

\section{Validitas \& Reliabilitas Alat Ukur}

Dalam penelitian ini validitas yang digunakan adalah validitas content. Validitas content suatu tes harus dapat mengukur sejauhmana aitem-aitem suatu tes dapat mencakup keseluruhan situasi yang ingin diukur oleh tes tersebut (Azwar, 1986). Validitas content berkaitan dengan kemampuan suatu instrument mengukur isi konsep yang harus diukur sehingga menggunakan langkah telaah dan revisi aitem-aitem pernyataan berdasarkan dari pendapat profesional.

Pengukuran reliabilitas dalam penelitian ini menggunakan alpha cronbach. Penelitian ini hanya memberikan satu kali pemberian tes terhadap partisipan sehingga pengukuran reliabilitas dengan menggunakan alpha cronbach cenderung dapat menguntungkan dari segi praktis dan ekonomis. Suatu konstruk dikatakan reliabel jika memberikan nilai Cronbach Alpha lebih dari 0,60 (Nunnaly, 1967).

\begin{tabular}{llllll}
\hline No. & $\begin{array}{l}\text { Dimen } \\
\text { si }\end{array}$ & $\begin{array}{l}\text { Favour } \\
\text { able }\end{array}$ & $\begin{array}{l}\text { Unfavo } \\
\text { urable }\end{array}$ & Total & Uji Daya Beda Aitem \\
\hline 1 & Penga & $4,7,9$, & 17 & 8 \\
\hline
\end{tabular}


Untuk menguji daya beda aitem dalam penelitian ini menggunakan uji korelasi Pearson Product Moment dengan bantuan Statistical Product and Service Solution (SPSS) 17.0 dan Microsoft Office Excel 2007. Pearson Product Moment digunakan untuk menyatakan ada tidaknya hubungan antara variabel komitmen organisasi dengan variabel kepemimpinan transformasional serta untuk menyatakan besarnya sumbangan variabel satu terhadap yang lainnya yang dinyatakan dalam persen.

\section{Hasil Uji Coba Alat Ukur Skala Komitmen Organisasi}

Dari hasil uji coba skala komitmen organisasi menunjukkan bahwa dari 24 aitem terdapat 13 aitem dengan daya beda yang tinggi dan 11 aitem yang gugur dengan daya beda lebih kecil dari 0,30 (Azwar, 2012) yaitu aitem nomor 2, 3, 4, 5, 6, 7, 9,10, 17, 19 dan 20.

Pada skala komitmen organisasi ini menunjukkan hasil reliabilitas dengan menggunakan Alpha Cronbach, maka diperoleh hasil $\mathrm{rxx}=0,640$ yang berarti tingkat reliabilitasnya baik.

Distribusi skala komitmen organisasi dapat dilihat pada tabel 3.3 berikut ini:

Tabel 3.3. Blue Print Skala Komitmen Organisasi Setelah Uji Coba

\begin{tabular}{lllll}
\hline No. & $\begin{array}{l}\text { Dimen } \\
\text { si }\end{array}$ & $\begin{array}{l}\text { Favourab } \\
\text { le }\end{array}$ & $\begin{array}{l}\text { Unfav } \\
\text { ourabl } \\
\text { e }\end{array}$ & Total \\
\hline 1 & $\begin{array}{l}\text { Komit } \\
\text { men }\end{array}$ & 1 & $\begin{array}{l}13,16, \\
\text { Afektif }\end{array}$ & 42 \\
& $\begin{array}{l}\text { Komit } \\
\text { men }\end{array}$ & & \\
2 & $\begin{array}{l}\text { Berkel } \\
\text { anjuta }\end{array}$ & $8,14,23$ & 11 & 4 \\
& $\begin{array}{l}\text { n } \\
\text { Komit }\end{array}$ & $12, \quad 15$, & \\
men & 18,21 & 5 \\
\hline
\end{tabular}

\begin{tabular}{llll}
\hline \multicolumn{1}{c}{$\begin{array}{c}\text { Norma } \\
\text { tif } \\
\text { Jumlah }\end{array}$} & & & \\
Total Aitem & 8 & 5 & 13 \\
\hline
\end{tabular}

\section{Skala Kepemimpinan Transformasional}

Dari hasil uji coba skala kepemimpinan transformasional menunjukkan bahwa dari 32 aitem terdapat 27 aitem dengan daya beda tinggi dan 5 aitem yang gugur dengan daya beda lebih kecil dari 0,30 (Azwar, 2012) yaitu aitem nomor 10, 17, 21, 22 dan 26.

Pada skala kepemimpinan transformsional ini menunjukkan hasil reliabilitas dengan menggunakan Alpha Cronbach, maka diperoleh hasil rxy= 0,933 yang berarti tingkat reliabilitasnya memuaskan

Distribusi skala kepemimpinan transformasional dapat dilihat pada tabel 3.4 berikut ini:

\section{Tabel 3.4 Blue Print Skala} Kepemimpinan Transformasional

\begin{tabular}{lllll}
\hline No. & $\begin{array}{l}\text { Dimen } \\
\text { si }\end{array}$ & $\begin{array}{l}\text { Favourabl } \\
\mathbf{e}\end{array}$ & $\begin{array}{l}\text { Unfavo } \\
\text { urable }\end{array}$ & Total \\
\hline 1 & $\begin{array}{l}\text { Penga } \\
\text { ruh }\end{array}$ & $\begin{array}{l}4,7,9,25, \\
29\end{array}$ & - & 5 \\
\hline
\end{tabular}




\begin{tabular}{|c|c|c|c|c|}
\hline & Ideal & & & \\
\hline 2 & $\begin{array}{l}\text { Motiva } \\
\text { si } \\
\text { Inspira } \\
\text { si }\end{array}$ & $\begin{array}{l}3,5,11,16, \\
18,30\end{array}$ & - & 6 \\
\hline 3 & $\begin{array}{l}\text { Stimul } \\
\text { asi } \\
\text { Intelek } \\
\text { tual }\end{array}$ & $\begin{array}{l}1,2,13,15, \\
19,31\end{array}$ & 23,27 & 8 \\
\hline 4 & $\begin{array}{l}\text { Perhati } \\
\text { an } \\
\text { Individ } \\
\text { ual }\end{array}$ & $\begin{array}{l}6,8,12,14, \\
20,24,28, \\
32\end{array}$ & - & 8 \\
\hline \multicolumn{2}{|c|}{$\begin{array}{l}\text { Jumlah } \\
\text { Total Aitem }\end{array}$} & 25 & 2 & 27 \\
\hline
\end{tabular}

\section{Analisa Data}

Data penelitian untuk melihat hubungan kepemimpinan transformasional dengan komitmen organisasi pada karyawan ini dianalisa dengan menggunakan Pearson Product Moment. Korelasi Pearson Product Moment merupakan salah satu teknik korelasi yang dapat menunjujjan seberapa besar hubungan yang terjadi antara dua variabel. Kedua variabel tersebut memiliki data berskala interval (Hadi, 2000). Sebelum data diolah dengan menggunakan bantuan Statistical Product and Service Solution (SPSS) 17.0 dan Microsoft Office Excel 2007, terlebih dahulu dilakukan uji asumsi berupa:

\section{Uji Normalitas}

Uji normalitas dilakukan untuk mengetahui apakah data penelitian kedua variabel terdistribusi secara normal. Pada penelitian ini uji normalitas yang dilakukan dengan menggunakan Normal $Q Q$ Plots. Data dinyatakan berdistribusi secara normal apabila hasil dari pengujiannya menunjukkan bahwa titik-titik nilai data terletak lebih kurang dalam suatu garis lurus.

\section{Uji Linearitas}

Uji linieritas hubungan dilakukan untuk mengetahui linier atau tidaknya hubungan antar variabel serta untuk mengetahui signifikansi penyimpangan dari linieritas hubungan tersebut. Jika terdapat penyimpangan yang tidak signifikan maka hubungan antara variabel bebas dan variabel tergantung dinyatakan linier. Uji linearitas dilakukan dengan menggunakan analisis statistik uji $\mathrm{F}$ dengan bantuan Statistical Product and Service Solution (SPSS) 17.0 dan Microsoft Office Excel 2007.

Kaidah yang digunakan untuk mengetahui linier atau tidaknya hubungan antar variabel adalah jika $\mathrm{p}<0.05$ maka hubungan antar variabel dinyatakan linier dan sebaliknya jika $\mathrm{p}>0.05$ maka hubungan antar variabel dinyatakan tidak linier (Hadi, 2000).

\section{DISKUSI}

\section{Gambaran Umum Subjek Penelitian}

Subjek penelitian adalah karyawan Kantor Pusat PT X dengan jumlah 193 orang. Berikut ini deskripsi umum subjek penelitian berdasarkan jenis kelamin, usia, masa kerja serta tingkat pendidikan.

\section{Gambaran Subjek Berdasarkan Jenis Kelamin \\ Berdasarkan jenis kelamin, penyebaran subjek penelitian dapat dilihat pada tabel 4.1 berikut ini:}

Tabel 4.1 Penyebaran Subjek Berdasarkan Jenis Kelamin

\begin{tabular}{cll}
\hline No $\begin{array}{l}\text { Jenis } \\
\text { Kelamin }\end{array}$ & $\begin{array}{l}\text { Jumlah } \\
(\mathrm{N})\end{array}$ & $\begin{array}{l}\text { Persen } \\
\text { tase }\end{array}$ \\
\hline
\end{tabular}




\begin{tabular}{lll}
\hline 1. Pria & 137 & $\mathbf{7 1 \%}$ \\
2. Wanita & 56 & $29 \%$ \\
Total & $\mathbf{1 9 3}$ & $\mathbf{1 0 0 \%}$ \\
\hline
\end{tabular}

Dari tabel 4.1 dapat diketahui bahwa mayoritas subjek penelitian adalah pria. Subjek pria berjumlah 137 orang (71\%) sedangkan subjek wanita berjumlah 56 orang $(29 \%)$.

\section{Gambaran \\ Berdasarkan Usia}

\section{Subjek}

Berdasarkan usia, penyebaran subjek penelitian dapat dilihat pada tabel 4.2 berikut ini:

Tabel 4.2 Penyebaran Subjek Berdasarkan Usia

\begin{tabular}{llll}
\hline No & Usia & $\begin{array}{l}\text { Jumlah } \\
(\mathbf{N})\end{array}$ & Persentase \\
\hline 1. & $\begin{array}{l}25-30 \\
\text { Tahun }\end{array}$ & 20 & $10,4 \%$ \\
2. $\begin{array}{l}\text { Tah-35 } \\
\text { Tahun }\end{array}$ & 38 & $19,7 \%$ \\
3. $\begin{array}{l}\text { 36-40 } \\
\text { Tahun }\end{array}$ & 50 & $25,9 \%$ \\
4. $\begin{array}{l}41-45 \\
\text { Tahun }\end{array}$ & 49 & $25,4 \%$ \\
5. $\begin{array}{l}46-50 \\
\text { Tahun }\end{array}$ & 23 & $11,9 \%$ \\
6. $\begin{array}{l}51-55 \\
\text { Tahun }\end{array}$ & 13 & $6,7 \%$ \\
Total & $\mathbf{1 9 3}$ & $\mathbf{1 0 0 \%}$ \\
\hline
\end{tabular}

Dari tabel 4.2 dapat dilihat bahwa jumlah subjek yang paling banyak berada pada rentang usia 36-40 tahun yaitu 50 orang $(25,9 \%)$, jumlah subjek pada rentang usia 41-45 tahun sebanyak 49 orang $(25,4 \%)$, jumlah subjek pada rentang usia 31-35 tahun sebanyak 38 orang $(19,7 \%)$, jumlah subjek pada rentang usia 46-50 tahun sebanyak 23 orang $(11,9 \%)$, jumlah subjek pada rentang usia 25-30 tahun sebanyak 20 orang $(10,4 \%)$ dan jumlah subjek yang berada pada rentang usia 51-55 tahun sebanyak 13 orang $(6,7 \%)$.

\section{Gambaran \\ Subjek Berdasarkan Masa Kerja}

Berdasarkan masa kerja, penyebaran subjek penelitian dapat dilihat pada tabel 4.3 berikut ini :

Tabel 4.3 Penyebaran Subjek Berdasarkan Masa Kerja

\begin{tabular}{|c|c|c|c|}
\hline No & $\begin{array}{l}\text { Masa } \\
\text { Kerja }\end{array}$ & Jumlah (N) & Persentase \\
\hline 1. & $\begin{array}{l}\text { 5-10 } \\
\text { Tahun }\end{array}$ & 66 & $34,2 \%$ \\
\hline 2. & $\begin{array}{l}11-15 \\
\text { Tahun }\end{array}$ & 37 & $19,2 \%$ \\
\hline 3. & $\begin{array}{l}16-20 \\
\text { Tahun }\end{array}$ & 50 & $25,9 \%$ \\
\hline 4 & $\begin{array}{l}21-25 \\
\text { Tahun }\end{array}$ & 16 & $8,3 \%$ \\
\hline 5 & $\begin{array}{l}26-30 \\
\text { Tahun }\end{array}$ & 20 & $10,3 \%$ \\
\hline 6 & >30 Tahun & 4 & $2,1 \%$ \\
\hline \multicolumn{2}{|c|}{ Total } & 193 & $100 \%$ \\
\hline
\end{tabular}

Dari tabel 4.3 dapat dilihat bahwa mayoritas subjek penelitian memiliki masa kerja 5-10 tahun yaitu 66 orang $(34,2 \%)$, subjek yang memiliki masa kerja 16-20 tahun sebanyak 50 orang $(25,9 \%)$, subjek dengan masa kerja 11-15 tahun sebanyak 37 orang $(19,2 \%)$, subjek dengan masa kerja 26-30 tahun sebanyak 20 orang $(10,3 \%)$, subjek dengan masa kerja 21-25 tahun sebanyak 16 orang $(8,3 \%)$ dan subjek dengan masa kerja lebih dari 30 tahun berjumlah 3 orang $(2,1 \%)$.

\section{Gambaran \\ Berdasarkan Pendidikan}

Subjek Tingkat

Berdasarkan tingkat pendidikan, penyebaran subjek penelitian dapat dilihat pada tabel 4.4 berikut ini: 
Tabel 4.4 Penyebaran Subjek Berdasarkan Tingkat Pendidikan

\begin{tabular}{|c|c|c|c|}
\hline No & $\begin{array}{l}\text { Tingkat } \\
\text { Pendidikan }\end{array}$ & $\begin{array}{l}\text { Jumlah } \\
\text { (N) }\end{array}$ & Persentase \\
\hline 1. & $\begin{array}{l}\text { Pasca Sarjana } \\
\text { (S2) }\end{array}$ & 8 & 4,1 \\
\hline 2. & Sarjana (S1) & 122 & $63,2 \%$ \\
\hline 3. & Diploma III & 4 & $2,1 \%$ \\
\hline 4. & SMA/Sederajat & 59 & $30,6 \%$ \\
\hline \multicolumn{2}{|c|}{ Total } & 193 & $100 \%$ \\
\hline
\end{tabular}

Dari tabel 4.4 dapat dilihat bahwa mayoritas subjek penelitian memiliki tingkat pendidikan Sarjana/S1 yaitu 122 orang $(63,2 \%)$, subjek dengan tingkat pendidikan SMA/Sederajat sebanyak 59 orang $(30,6 \%)$, subjek dengan tingkat pendidikan paska sarjana/S2 sebanyak 8 orang $(4,1 \%)$ dan subjek dengan tingkat pendidikan Diploma III sebanyak 4 orang $(2,1 \%)$.

\section{Uji Normalitas}

Uji normalitas bertujuan untuk mengetahui apakah populasi data penelitian berdistribusi secara normal dalam kurva sebaran normalitas. Hasil uji normalitas menggunakan Normal $Q Q$ Plots. Pengujian ini menyatakan data berdistribusi normal apabila titiktitik nilai data terletak kurang lebih dalam suatu garis lurus. Hasil uji normalitas dengan normal $Q Q$ plots dapat dilihat dalam grafik berikut:

\section{Uji Normalitas Variabel Kepemimpinan Transformasional}

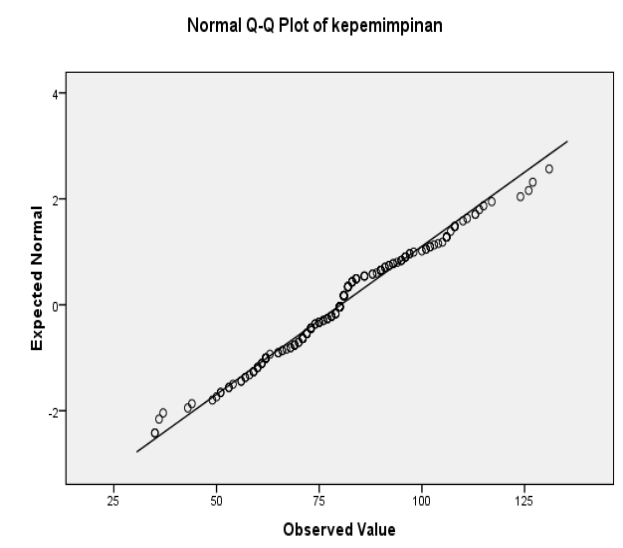

Grafik 4.1 Uji Normalitas Kepemimpinan Transfomasional

Dari grafik 4.1 dapat dilihat bahwa titik-titik nilai dari variabel kepemimpinan transformasional kurang lebih berada dalam satu garis lurus. Hal ini menunjukan bahwa variabel kepemimpinan transformasional berasal dari populasi yang berdistribusi normal.

\section{a. Uji Normalitas Variabel Komitmen Organisasi}

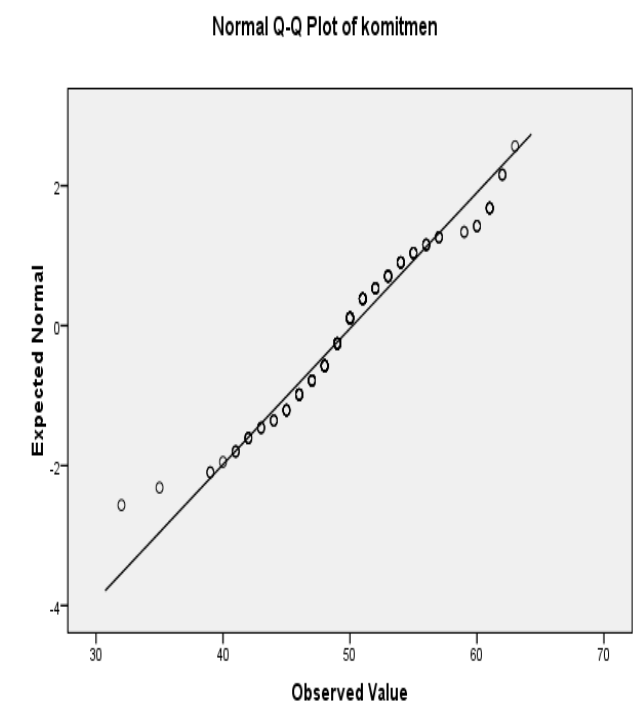

Grafik 4.2 Uji Normalitas Komitmen Organisasi 
Dari grafik 4.2 dapat dilihat bahwa titik-titik nilai dari variabel komitmen organisasi kurang lebih berada dalam satu garis lurus. Hal ini menunjukan bahwa variabel komitmen organisasi berasal dari populasi yang berdistribusi normal.

\section{Uji Linearitas}

Uji linearitas bertujuan untuk mengetahui apakah dua variabel mempunyai hubungan yang linear atau tidak secara signifikan. Dalam penelitian ini uji linearitas akan melihat apakah dua variabel penelitian ini yaitu kepemimpinan transformasional dan komitmen organisasi memiliki korelasi untuk memenuhi garis linear. Hasil uji linearitas sebagai berikut:

Tabel 4.5 Hasil Uji Linearitas

\begin{tabular}{lllll}
\hline No & Variabel & Linearity & $\mathbf{F}$ & Kesimpulan \\
\hline 1. & $\begin{array}{l}\text { Komitmen* } \\
\text { Kepemimpinan }\end{array}$ & 0.000 & 27.500 & $\begin{array}{l}\text { Hubungan } \\
\text { Linear }\end{array}$ \\
\hline
\end{tabular}

Berdasarkan tabel 4.5, dapat diperoleh linearitas 0,000 untuk variabel komitmen dan kepemimpinan. Hal ini dapat menunjukkan bahwa nilai linearity dibawah 0,05 sehingga telah memenuhi asumsi linearitas.

Tujuan utama dari penelitian ini adalah untuk mengetahui hubungan kepemimpinan transformasional dengan komitmen organisasi. Untuk dapat menguji hubungan kepemimpinan transformasional dengan komitmen organisasi yang dalam hal ini komitmen organisasi terbagi atas tiga dimensi yaitu komitmen afektif, komitmen berkelanjutan dan komitmen normatif digunakan analisis Pearson Product Moment.

\section{Korelasi antara Kepemimpinan Transformasional Komitmen Afektif}

Analisis pearson product moment dengan bantuan aplikasi komputer program SPSS 17.0 for windows dan Microsoft Office Excel 2007 digunakan untuk untuk dapat mengetahui hubungan antara kepemimpinan transformasional dengan komitmen afektif.

Tabel 4.6 Korelasi antara Kepemimpinan Transformasional dengan Komitmen Afektif

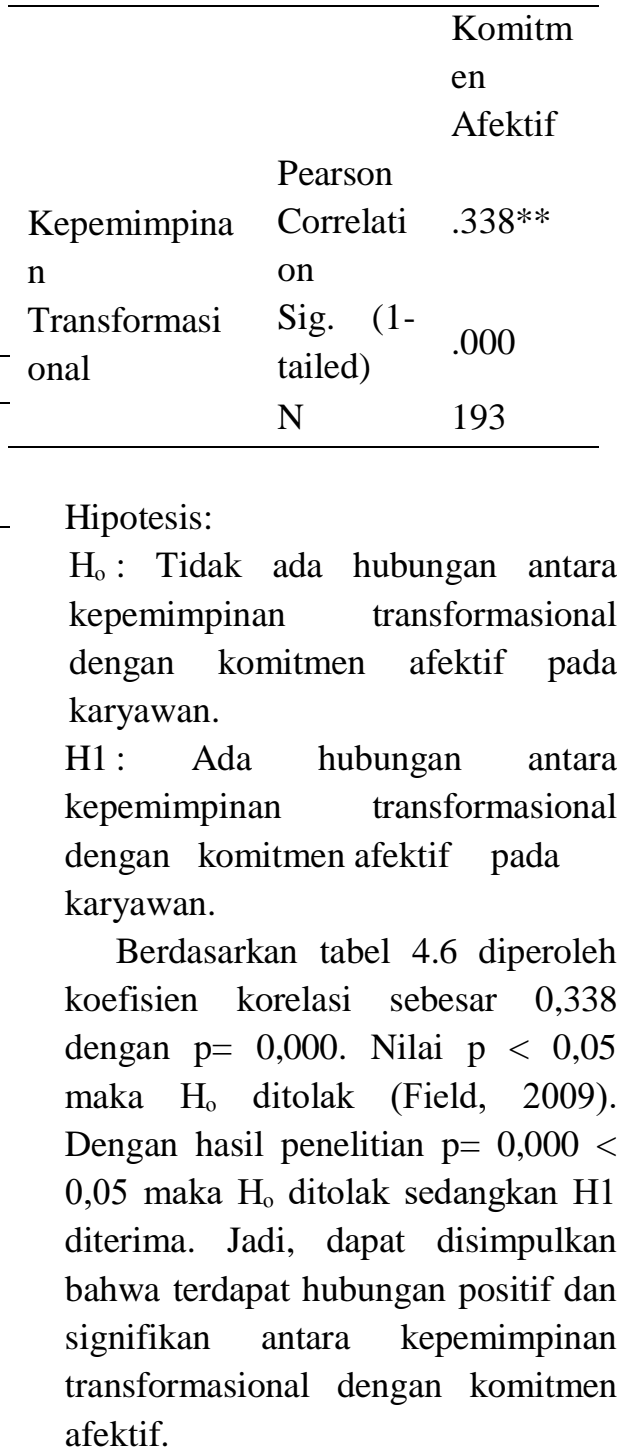


2. Korelasi antara Kepemimpinan Transformasional dengan Komitmen Berkelanjutan

Analisis pearson product moment dengan bantuan aplikasi komputer program SPSS 17.0 for windows dan Microsoft Office Excel 2007 digunakan untuk dapat mengetahui hubungan antara kepemimpinan transformasional dengan komitmen berkelanjutan.

Tabel 4.7 Korelasi antara Kepemimpinan Transformasional dengan Komitmen Berkelanjutan

\begin{tabular}{|c|c|c|}
\hline & & $\begin{array}{l}\text { Komitme } \\
\mathrm{n} \\
\text { Berkelanj } \\
\text { utan }\end{array}$ \\
\hline & Pearson & \\
\hline $\begin{array}{l}\text { Kepemimpin } \\
\text { an }\end{array}$ & $\begin{array}{l}\text { Correlat } \\
\text { ion }\end{array}$ & $.211^{* *}$ \\
\hline $\begin{array}{l}\text { Transformasi } \\
\text { onal }\end{array}$ & $\begin{array}{l}\text { Sig. (1- } \\
\text { tailed) }\end{array}$ & .002 \\
\hline & $\mathrm{N}$ & 193 \\
\hline
\end{tabular}

Hipotesis:

$\mathrm{H}_{\mathrm{o}}$ : Tidak ada hubungan antara kepemimpinan transformasional dengan komitmen berkelanjutan pada karyawan.

H1 : Ada hubungan antara kepemimpinan transformasional dengan komitmen berkelanjutan pada karyawan.

Berdasarkan tabel 4.7 diperoleh koefisien korelasi sebesar 0,211 dengan $\mathrm{p}=0,002$. Nilai $\mathrm{p}<0,05$ maka $\mathrm{H}_{\mathrm{o}}$ ditolak (Field, 2009). Dengan hasil penelitian $\mathrm{p}=0,002<$ 0,05 maka $\mathrm{H}_{\mathrm{o}}$ ditolak sedangkan $\mathrm{H} 1$ diterima. Jadi, dapat disimpulkan bahwa terdapat hubungan positif dan signifikan antara kepemimpinan transformasional dengan komitmen berkelanjutan.

\section{Korelasi antara Kepemimpinan Transformasional dengan Komitmen Normatif}

Analisis pearson product moment dengan bantuan aplikasi komputer program SPSS 17.0 for windows dan Microsoft Office Excel 2007 digunakan untuk dapat mengetahui hubungan antara kepemimpinan transformasional dengan komitmen normatif.

Tabel 4.8 Korelasi antara Kepemimpinan Transformasional dengan Komitmen Normatif

\begin{tabular}{lll}
\hline & & $\begin{array}{l}\text { Komitm } \\
\text { en } \\
\text { Normati } \\
\end{array}$ \\
& & $\mathrm{f}$ \\
& Pearson \\
Kepemimpina & $\begin{array}{l}\text { Correlati } \\
\text { on }\end{array}$ & $.201 * *$ \\
Transformasi & Sig. $\quad(1-$ & .003 \\
onal & tailed) & \\
& $\mathrm{N}$ & 193 \\
\hline
\end{tabular}

Hipotesis:

$\mathrm{H}_{\mathrm{o}}$ : Tidak ada hubungan antara kepemimpinan transformasional dengan komitmen normatif pada karyawan.

H1 : Ada hubungan antara kepemimpinan transformasional dengan komitmen normatif pada karyawan.

Berdasarkan tabel 4.8 diperoleh koefisien korelasi sebesar 0,201 dengan $\mathrm{p}=0,003$. Nilai $\mathrm{p}<0,05$ maka $\mathrm{H}_{0}$ ditolak (Field, 2009). Dengan hasil penelitian $\mathrm{p}=0,003<$ 0,05 maka $\mathrm{H}_{\mathrm{o}}$ ditolak sedangkan $\mathrm{H} 1$ diterima. Jadi, dapat disimpulkan bahwa terdapat hubungan positif dan signifikan antara kepemimpinan 
transformasional dengan komitmen normatif.

Hasil penelitian pada karyawan PDAM Tirtanadi menunjukkan bahwa terdapat hubungan positif dan signifikan antara kepemimpinan transformasional dengan komitmen afektif, komitmen normatif dan komitmen berkelanjutan. Hal ini sejalan dengan pendapat Bass (1985) yang menyatakan bahwa pemimpin transformasional memiliki kemampuan untuk menciptakan komitmen yang tinggi pada karyawan.

Hasil penelitian menununjukkan bahwa terdapat hubungan kepeminpinan transformasional dengan komitmen afektif dengan analisis pearson product moment diperoleh korelasi (r) sebesar 0.338 dengan $\mathrm{p}=0.000$, terdapat hubungan antara kepemimpinan transformasional dengan komitmen berkelanjutan dengan analisis pearson product moment diperoleh korelasi (r) sebesar 0.211 dengan $\mathrm{p}=0.002$, dan terdapat hubungan antara kepemimpinan transformasional dengan komitmen normatif dengan analisis pearson product moment diperoleh korelasi (r) sebesar 0.201 dengan $\mathrm{p}=0.003$.

Klasifikasi kekuatan hubungan mulai dari korelasi sangat lemah hingga sangat kuat yaitu 1 . Korelasi sangat lemah $(0.001$ - 0.200), 2. Korelasi lemah $(0.200-$ $0.400), 3$. Korelasi cukup kuat $(0.400-$ $0.600)$, 4. Korelasi kuat $(0.600-0.800)$ dan 5. Korelasi sangat kuat $(0.800-1)$. Berdasarkan klasifikasi tersebut menunjukkan bahwa terdapat hubungan positif antara kepemimpinan transformasional dengan komitmen afektif dengan kekuatan korelasi sebesar 0,338 yang tergolong lemah, terdapat hubungan positif antara kepemimpinan transformasional dengan komitmen berkelanjutan dengan kekuatan korelasi sebesar 0,211 yang tergolong lemah dan terdapat hubungan positif antara kepemimpinan transformasional dengan komitmen normatif dengan kekuatan korelasi sebesar 0,201 yang tergolong lemah.

Dari hasil penelitian yang menunjukkan bahwa komitmen afektif memiliki hubungan positif yang lebih kuat terhadap kepemimpinan transformasional daripada komitmen berkelanjutan dan komitmen normatif. Dalam konteks penelitian ini dapat dikatakan bahwa karyawan yang memiliki komitmen afektif akan lebih bernilai bagi perusahaan dibandingkan karyawan yang memiliki komitmen berkelanjutan dan komitmen normatif. Rhoades dkk (2001) menyatakan bahwa seseorang dengan komitmen afektif terhadap organisasi akan memperlihatkan performansi kerja yang tinggi. Karyawan di perusahaan ini yang memiliki komitmen afektif tak hanya sekedar merasa bagian dari perusahaan, tetapi ia juga bersedia untuk mengupayakan segala yang terbaik bagi perusahaan, serta membantu dalam mencapai tujuan perusahaan.

Hasil penelitian menunjukkan bahwa kepemimpinan transformasional memiliki hubungan positif terhadap komitmen berkelanjutan. Komitmen berkelanjutan menurut Dunham dkk (1994) adalah keadaan dimana karyawan merasa membutuhkan untuk tetap tinggal dalam organisasi. Karyawan di perusahaan ini memiliki kesararan jika ia akan mengalami kerugian yang besar jika meninggalkan perusahaan ini. Dalam hal ini, pemimpin transformasional memotivasi karyawan dengan meningkatkan arti penting dan nilai tugas bagi karyawan serta mendorong karyawan untuk lebih mengutamakan kepentingan perusahaan dengan meningkatkan tingkat kebutuhan karyawan ke taraf yang lebih tinggi (Stoner dkk, 1995). Karyawan akan 
lebih berkontribusi pada perusahaan ini karena perusahaan ini dapat memenuhi kebutuhan karyawan dapat dilihat dengan peningkatan gaji dan tunjangan serta hari kerja yang mulai dari senin hingga jumat saja.

Selanjutnya, dari hasil penelitian juga menunjukkan bahwa kepemimpinan transformasional memiliki hubungan positif terhadap komitmen normatif. Berdasarkan teori Brown dan Gaylor (2002) komitmen normatif dikarakteristikkan dengan keyakinan dari karyawan bahwa dia berkewajiban untuk bertahan dalam suatu perusahaan tertentu karena suatu loyalitas personal, dengan kata lain karyawan di perusahaan ini yang memiliki komitmen normatif yang tinggi akan bertahan karena mereka merasa harus melakukan hal tersebut. Mereka merasa wajib bertahan diperusahaan ini atas dasar keharusan.

Menurut Yukl (2005) kepemimpinan transformasional dapat dilihat dari tingginya komitmen, motivasi dan kepercayaan bawahan sehingga melihat tujuan organisasi yang ingin dicapai lebih dari sekedar kepentingan pribadinya. Hal ini dapat dilihat dari hasil penelitian bahwa persentase karyawan yang memiliki komitmen afektif yang tinggi sebesar $81,4 \%$, disusul dengan komitmen normatif yang tinggi yaitu sebesar $71,5 \%$ lalu komitmen berkelanjutan sebesar $63,2 \%$.

Pada penelitian ini juga mencantumkan gambaran subjek penelitian berdasarkan jenis kelamin, usia, masa kerja dan tingkat pendidikan. Berdasarkan jenis kelamin, sebagian besar karyawan di perusahaan ini berjenis kelamin laki-laki yaitu sebesar $71 \%$. Berdasarkan usia, sebagian besar karyawan berada dalam rentang usia 3645 tahun yakni sebesar 51,3\%. Berdasarkan masa kerja, sebagian besar karyawan sudah bekerja di perusahaan ini selama 5-15 tahun yaitu sebesar 53,4\%. Berdasarkan tingkat pendidikan, sebagian besar karyawan berada di tingkat pendidikan sarjana (S1) yakni sebesar $63,2 \%$.

\section{KESIMPULAN}

Berdasarkan hasil penelitian kepemimpinan transformasional dengan komitmen organisasi pada karyawan PT X dapat disimpulkan beberapa hal, yaitu:

1. Terdapat hubungan positif dan signifikan antara kepemimpinan transformasional dengan komitmen afektif dengan kekuatan korelasi sebesar 0,338 yang berarti pada kategori lemah.

2. Terdapat hubungan positif dan signifikan antara kepemimpinan transformasional dengan komitmen berkelanjutan dengan kekuatan korelasi sebesar 0,211 yang berarti pada kategori lemah.

3. Terdapat hubungan positif dan signifikan antara kepemimpinan transformasional dengan komitmen normatif dengan kekuatan korelasi sebesar 0,201 yang berarti pada kategori lemah.

4. Karyawan di perusahaan ini memiliki komitmen afektif $(81,4 \%)$ yang lebih kuat ketimbang komitmen berkelanjutan $(63,2 \%)$ dan komitmen normatif $(71,5 \%)$.

\section{SARAN}

Sesuai dengan penelitian dan kesimpulan yang telah dikemukakan makan peneliti memberikan beberapa saran. Diharapkan saran-saran berikut nantinya akan berguna bagi pengembangan studi ilmiah khususnya psikologi industri dan organisasi serta bermanfaat bagi pihak perusahaan: 
1. Saran Metodologis

a. Pendampingan dalam pengisian kuisioner diperlukan untuk dapat meminimalisir adanya ketidaklengkapan data dan juga pengisian seluruh aitem pada kuisioner.

b. Untuk peneliti selanjutnya yang tertarik meneliti tentang komitmen organisasi dapat menggunakan subjek penelitian dari berbagai perusahaan.

\section{Saran Praktis}

a. Pimpinan memegang peranan penting di perusahaan. Merujuk pada hasil penelitian yang menunjukkan bahwa kepemimpinan transformasional dalam kategori sedang sebaiknya agar perlu ditingkatkan.

b. Dengan mayoritas karyawan memiliki komitmen yang tinggi baik itu komitmen afektif, komitmen berkelanjutan dan komitmen normatif sebaiknya dipertahankan dan juga memungkinkan untuk semakin ditingkatkan. Peningkatan dapat dilakukan dengan cara perusahaan membuat suatu program yang didesain untuk membuat karyawan merasa lebih terikat dengan perusahaan serta program untuk membuat karyawan lebih memahami visi dan misi perusahaan sehingga karyawan mampu berupaya untuk membantu perusahaan dalam hal mencapai tujuan-tujuan perusahaan.

\section{REFERENSI}

Ancok, D. 2012. Psikologi Kepemimpinan \& Inovasi. Jakarta: Erlangga.

Azwar, S. 1986. Reliabilitas dan Validitas. Yogyakarta: Liberty.
Azwar, S. 2010. Metode Penelitian. Yogyakarta: Pustaka Pelajar.

Bass, B. M. 1985. Leadership and Performance Beyond Expectation. New York: Free Press.

Bass, B. M. dan Avolio, B. J. 1994. Improving Organizational Effectiveness Through Transformational Leadership. Thousand Oaks, CA: Sage.

Bass, B. M., Avolio, B. J., \& Jung, D. I. 1999. Re-examining the components of transformational and transactional leadership using the multifactor leadership questionnaire. Journal of Occupational and Organizational Psychology, 72, 441-462.

Budiarto, Y \& Selly. 2004. Komitmen Karyawan pada Perusahaan ditinjau dari Kepemimpinan Transformasional dan Transaksional. Jurnal Psikologi Vol. 2 No 2, Desember 2004.

Field, A. 2009. Discovering Statistic Using SPSS, $3^{\text {rd }}$ edition. London: SAGE Publication Ltd.

Daft, R. L. 1999. Leadership: Theory and Practice. Texas: The Dryden Press, Harcourt Brace \& Company.

Desianty, S. 2005. Pengaruh Gaya Kepemimpinan terhadap Komitmen Organisasi pada PT POS Indonesia (Persero) Semarang. Jurnal Studi Manajemen \& Organisasi Vol. 2 No. 1, Januari 2005.

Greenberg, J., \& Baron, R. A. 1997. Behavior in organizations. 
Understanding and managing the human side of work. New Jersey: Prentice-Hall.

Hadi. 2000. Metodology Research. Yogyakarta: Andi.

Ismail, A., Mohamed H. A., dkk. 2011. An Empirical Study Of the Relationship between Transformational Leadership, Empowerment and Organizational Commitment. Business and Economics Research Journal. Vol. 2 No. 1. 2011.

Kamus Besar Bahasa Indonesia Online. Definisi Karyawan. http://kbbi.web.id/karyawan. Diakses pada tanggal 1 Desember 2013.

Jaros, S. 2007. Meyer and Allen Model of Organizational Commitment: Measurement Issues. The Icfai Journal of Organizational Behavior Vol. VI, No. 4.

Meyer, J. P \& Allen, N. J. 1990. The measurement and antecedents of affective, continuance, and normative commitment to the organization. Journal of Occupational Psychology, 63, 118.

Meyer, J. P \& Allen, N. J. 1997. Commitment in the workplace. Theory, research and application. California: Sage Publication.

Meyer, J. P., Allen, N. J., \& Smith, C. A. 1993. Commitment to organizational and occupations: Extension and test of a three component conceptualization. Journal of Applied Psychology, 78 (4), 538- 551.
Muhdiyanto. 2011. Kepemimpinan Tranformasional dan Komitmen Organisasional: Pemberdayaan sebagai Variabel Mediasi. Seminar Nasional Ilmu Ekonomi Terapan 59 Fakultas Ekonomi UNIMUS 2011.

Northouse, P. G. 2013. Kepemimpinan, Teori dan Praktik Edisi Keenam. Jakarta: PT. Indeks.

Portalhr. 2005. Membedah Pandangan Karyawan Indonesia. http://www.portalhr.com. Diakses pada tanggal 10 November 2014.

Rhoades, L., EIsenberger, R.,\& Armeli, S. 2001. Affective Commitment to Organization: The Contribution of Perceived Organizational Support. Journal of Applied Psychology. 86. 5. 825-836

Rizadinata. 2013. Hubungan Antara Kepemimpinan Transformasional dengan Komitmen Organisasi pada Karyawan Divisi Produksi PT. Gunawan Dianjaya Steel Surabaya. Jurnal Psikologi Industri Organisasi Vol. 2 No. 1, Februari 2013.

Robbins, S R. dan Timothy A. J. 2008. Perilaku Organisasi Edisi ke-12 Buku 1 \& 2. Jakarta: Salemba Empat.

Steers, M. R., Lyman W. P. 1979. The Measurement of Organizational Commitment. Journal of Vocational Behaviour. 14, 224247.

Steers, R. M., \& Porter, L. W. 1983. Motivation and Work Behavior. New York, NY: McGraw-Hill 
Suryabrata, S. 2011. Metodologi

Penelitian. Jakarta: PT. Raja

Grafindo Persada. 